\title{
What drives reindeer management in Finland towards social and ecological tipping points?
}

\author{
Mia Landauer ${ }^{1,2}$ (D) Sirpa Rasmus ${ }^{1}$ (iD $\cdot$ Bruce C. Forbes $^{1}$ (D) \\ Received: 11 November 2019 / Accepted: 6 February 2021 / Published online: 20 March 2021 \\ (C) The Author(s) 2021
}

\begin{abstract}
Reindeer management (RM) in northern Fennoscandia is an example of social-ecological systems (SESs) providing social, cultural, ecological, and economic values. Changing climate and pasture conditions and societal changes continue to transform the operational environment of RM. These key drivers, and resulting transformations including alternative SES states, have not been studied in detail before. Our comprehensive literature review and interviews with herders reveal that land use, climate change, and governance drive the emergence of SES tipping points. The basis of successful RM depends on the quantity and quality of pastures to secure animal fitness. However, intensive forestry, extreme weather, and predators constrain the availability of forage and suitable calving grounds. Maintaining RM by means of predation compensation mechanisms and regular supplementary winter feeding to adapt to changes brought about by land use and warming climate comprises an alternative system state. However, if negative impacts increase remarkably or rapidly and compensatory mechanisms become insufficient, long-term impacts on system identity, and even local collapses, are expected. Although some environmental and societal changes are perceived as pressures by herders, they can be beneficial for other livelihoods in the region. Therefore, our study raises questions for future studies on social justice, such as who has the right to decide what constitutes a desirable system state, or what collaborative efforts to maintain RM in Fennoscandia would entail. Our work is applicable also in other Arctic/sub-Arctic regions where nature-based livelihoods, such as small-scale forestry and agriculture, hunting, traditional fishing, and gathering are practiced.
\end{abstract}

Keywords Social-ecological system $\cdot$ Land use $\cdot$ Climate change $\cdot$ Adaptation $\cdot$ Traditional livelihoods $\cdot$ Arctic

\section{Introduction}

\section{Reindeer management, a complex social-ecological system in transformation}

Communicated by Diana Sietz

Mia Landauer

mia.landauer@ulapland.fi

Sirpa Rasmus

sirpa.rasmus@ulapland.fi

Bruce C. Forbes

bforbes@ulapland.fi

1 Arctic Centre, University of Lapland, P.O. Box 122, FI-96101 Rovaniemi, Finland

2 Systemic Risk and Resilience Group, International Institute for Applied Systems Analysis (IIASA), Schlossplatz 1, A-2361 Laxenburg, Austria
Reindeer management (RM) in northern Fennoscandia is an example of social-ecological systems (SESs) (see e.g., Ostrom 2009; McGinnis and Ostrom 2014). It encompasses different types of environments, resources, actors, and governance as illustrated by Käyhkö and Horstkotte (2017, p. 16). RM provides social, cultural, ecological, and economic values not only for the indigenous Sámi of northernmost Finland, but also for other mixed-ethnicity and local communities practicing modern herding. It lies at the nexus of locally and regionally significant cultures and traditions, as well as ecosystem services which are tied to diverse pasture landscapes encompassing forests, fells and mires. Local topography, climatic characteristics, pasture conditions and relations with other livelihoods have influenced the operational environment 
of RM for centuries and shaped the local herding practices. Co-existence of economic activities and traditional livelihoods sharing the same operational space is challenging to pastoral systems. This is because other land use limits access to forage and can also lead to loss of pastures that serve as the natural resource base for RM (Kumpula et al. 2014; Kivinen 2015; Turunen et al. 2020).

Warming climate and increasingly extreme weather affect herding conditions in Fennoscandia via shrubification of open fells and more frequent ice-locked pastures, for example (Myers-Smith et al. 2015; Forbes et al. 2016; Horstkotte et al. 2017; Rasmus et al. 2018, 2020). As a result of climate change mitigation actions, national policies have increased the demand for renewable energy such as wind, hydropower, and biomass in Finland (Ministry of Economic Affairs and Employment 2017), increasing land use pressures within the RM area. Conflicts with other land users and governance misfits have been reported also in other Fennoscandian (Johnsen 2016; Keskitalo et al. 2016; Suopajärvi et al. 2017), as well as Russian (Forbes 2013; Sidortsov et al. 2016) and Mongolian (Endicott 2012; McIntyre et al. 2016) pastoral communities.

Top-down governance of RM has been driving changes that have affected herding traditions and culture in Finland for centuries. For example, in the nineteenth century, Sámi herders experienced a loss of their nomadic culture due to the closing of international borders to Norway in 1852, and to Sweden and Russia in 1889, which forced them to a more stationary life and some moved with their herds further south (Heikkinen 2006, 2007). Establishment of the reindeer cooperative system (paliskunnat) in Finland not only affected the nomadic Sámi culture but RM as a whole (Heikkinen 2006).

Regarding governance, another gradual shift in RM is illustrated by the steady increase in the number of predators since Finland joined the EU in 1995: predator populations have recovered due to changes in the large carnivore protection policy. Increasing predation pressure increases the workload and costs of RM, and the predator-caused reindeer losses have more than doubled during the last decade compared to the $1990 \mathrm{~s}$ (Heikkinen et al. 2011; Turunen et al. 2017). The other side of the coin is that the EU's nature conservation policy, in particular the establishment of Natura 2000 areas, has been beneficial for $\mathrm{RM}$ in that it aims to protect old growth forests - a critical winter pasture resource for reindeer-from other land use.

\section{Conceptual background}

In the literature, SESs are described as interlinked systems that are constantly changing and affected by human decisions and agency (e.g., Ostrom 2007). In general, significant change within an SES can potentially shift the system into an alternative state if a tipping point is crossed. The consequences of transformation can be perceived in constrasting ways by different actors and across regions. Impacts on cultural identity or economic base are perceived by some as critical and considered as a loss of important characteristics of RM (see e.g., Lépy et al. 2018). An alternative state can mean a RM, that has faced substantial changes and has become fundamentally different compared to the state it previously was. But what is considered "fundamentally different" depends on the point of view. For example, Sámi herders might perceive that the $\mathrm{RM}$ system is tipping into an alternative state if its cultural identity is significantly affected even if the economic viability can be maintained. Therefore, social and ecological tipping phenomena need to be studied together.

Another type of an alternative state is loss of the RM system; 'collapse.' Predictive challenges, in particular from the perspective of social tipping points ${ }^{1}$, are involved in identifying when a tipping point is approaching (cf. Milkoreit et al. 2018), and there is a lack of understanding of why and when the system is about to "collapse" (Cumming and Peterson 2017). It is also difficult to assess qualitatively what the alternative states might be, or calculate the magnitude of non-linear changes quantitatively (Wassmann and Lenton 2012; Milkoreit et al. 2018). According to Cumming and Peterson (2017, pp. 688-689), understanding the identity of the current system is the first step towards assessing change and its consequent impacts. Their framework also illustrates well the elements of potential collapse processes: (i) "The identity of the social-ecological system must be lost" (economic, socio-cultural and/or ecological identity), (ii) "Loss of identity should happen fast" (rapid vs. gradual change), (iii) "Collapse involves substantial losses of social-ecological capital" (reparable vs. irreversible losses), and (iv) "The consequences of collapse must be lasting" (short- vs. long-term consequences). RM provides examples of these, although full-scale collapse of RM in Finland has not been experienced and the loss of the livelihood would probably take place only locally in herding cooperative scale.

\section{From incremental to transformative adaptation in reindeer management}

The ways in which potential system transformation within RM takes place depends on the magnitude of change affecting critical resources, the environment, its users (actors), and units of the SES: the pastures and reindeer herders; well-being of animals and herd productivity, as well as culture and traditions (Käyhkö and Horstkotte 2017). This also depends on the accumulation of changes across time and space, as well as adaptive capacity. Thus, the different facets of adaptation to reduce

\footnotetext{
1 “... a social tipping point can be defined as a point within an SES at which a small quantitative change inevitably triggers a non-linear change in the social component of the SES, driven by a self-reinforcing positive feedback mechanisms, that inevitably and often irreversibly lead to a qualitatively different state of the social system." (Milkoreit et al. 2018, p. 10)
} 
potential harm to the SES should be understood (Table 1; Pelling 2010).

In order to maintain the viability of Arctic traditional livelihoods, adaptive and participatory forms of governance are essential. However, state adaptation budgets are often limited and decision-making power is not equally distributed (Huntington et al. 2012; Landauer and Juhola 2019). This also applies to reindeer herders in Finland who bear the risks and costs of extreme weather and land use change. In RM, short-term coping has taken place as a response to emerging conditions (Turunen et al. 2016). However, such changes can be rapid and difficult to predict, and their long-term and system-wide consequences

Table 1 Definitions of commonly used adaptation terminology and examples related to reindeer management. Several definitions originate in the climate change adaptation literature, but they are applicable to other types of change, such as land use changes. The terms 'coping' and remain uncertain. Thus, incremental adaptation alone may not be enough (cf. Lonsdale et al. 2015). RM as a SES in Finland is highly complex and requires in-depth understanding of forward-looking, transformational adaptation. This might include actions that differ radically from the current system to avoid potential power imbalance and non-adaptive management (cf. Berkes 2010).

\section{Aim and approach}

Our case study (sensu Yin 2013) examines the SES of RM in Finland based on a comprehensive literature review and

'adaptation,' especially 'incremental adaptation,' are difficult to distinguish from each other, and certain actions may be classified differently by different authors (cf. Lonsdale et al. 2015)

\begin{tabular}{|c|c|c|c|c|}
\hline Term & Definition & Reference & Examples reindeer management & Reference \\
\hline Coping & $\begin{array}{l}\text { "The use of available skills, resources, } \\
\text { and opportunities to address, manage, } \\
\text { and overcome adverse conditions, } \\
\text { with the aim of achieving basic } \\
\text { functioning in the short to medium } \\
\text { term." }\end{array}$ & IPCC (2012 p. 558) & $\begin{array}{l}\text { Herders intensify the use of pasture } \\
\text { diversity by pasture rotation } \\
\text { methods } \\
\text { Changes in the annual cycle in the } \\
\text { pasture use due to } \\
\text { environmental changes }\end{array}$ & $\begin{array}{l}\text { Turunen et al. (2016) } \\
\text { Sarkki et al. (2016) } \\
\text { Forbes et al. (2020) }\end{array}$ \\
\hline Adaptation & $\begin{array}{l}\text { "...the process of adjustment to actual } \\
\text { or expected climate and its effects, } \\
\text { in order to moderate harm or exploit } \\
\text { beneficial opportunities." } \\
\text { "... process of deliberate change in } \\
\text { anticipation of or in reaction to } \\
\text { external stimuli and stress." }\end{array}$ & $\begin{array}{l}\text { IPCC (2012 p. 556) } \\
\text { Nelson et al. }(2007 \\
\text { p. } 395)\end{array}$ & Supplementary feeding & \\
\hline $\begin{array}{l}\text { Incremental } \\
\text { adaptation }\end{array}$ & $\begin{array}{l}\text { "...extensions of actions and behaviors } \\
\text { that already reduce the losses or } \\
\text { enhance the benefits of natural } \\
\text { variations in climate and extreme } \\
\text { events." }\end{array}$ & $\begin{array}{l}\text { Kates et al. (2012 p. } \\
\text { 7157) }\end{array}$ & & \\
\hline $\begin{array}{l}\text { Transformative } \\
\text { adaptation }\end{array}$ & $\begin{array}{l}\text { “...adopted at a much larger scale or } \\
\text { intensity; truly new to a particular } \\
\text { region or resource system, and those } \\
\text { that transform places and shift } \\
\text { locations. ...collective adaptations } \\
\text { that would be explicitly planned } \\
\text { and implemented; autonomous } \\
\text { adaptations by individuals } \\
\text { and organizations that can } \\
\text { cumulate in transformative } \\
\text { adaptations; actions intended } \\
\text { to address other problems } \\
\text { that can become } \\
\text { transformative adaptations." }\end{array}$ & $\begin{array}{l}\text { Kates et al. } \\
\quad(2012 \text { p. } 7156)\end{array}$ & $\begin{array}{l}\text { “...institutional frames for long-term } \\
\text { adaptation and the role of other society } \\
\text { in enabling or blocking alternatives, such } \\
\text { as topical environmental legislation and } \\
\text { economic subsidy and compensation } \\
\text { systems.” }\end{array}$ & $\begin{array}{l}\text { Lépy et al. (2018, p. } \\
216)\end{array}$ \\
\hline Adaptive capacity & $\begin{array}{l}\text { "The combination of the strengths, } \\
\text { attributes, and resources available } \\
\text { to an individual, community, } \\
\text { society, or organization that can } \\
\text { be used to prepare for and } \\
\text { undertake actions to reduce } \\
\text { adverse impacts, moderate } \\
\text { harm, or exploit beneficial } \\
\text { opportunities." }\end{array}$ & IPCC (2012 p. 556) & $\begin{array}{l}\text { Available social, institutional, } \\
\text { human, economic and } \\
\text { cultural capital to } \\
\text { adapt to change }\end{array}$ & $\begin{array}{l}\text { Buchanan et al. } \\
\text { (2016) }\end{array}$ \\
\hline Limit to adaptation & $\begin{array}{l}\text { "...a level of adaptive capacity, } \\
\text { broadly defined, that cannot } \\
\text { be surpassed." }\end{array}$ & Dow et al. (2013 p. 305) & $\begin{array}{l}\text { Lack of participation and uneven } \\
\text { distribution of power }\end{array}$ & Löf (2013) \\
\hline
\end{tabular}


empirical data based on interviews with key practitioners. By means of the case study, we aim to analyze drivers of changes affecting the SES that trigger system tipping and transform it into an alternative state which can even appear as loss of the system (collapse) if adaptation options are limited (Dow et al. 2013; Löf 2013). We examine social tipping phenomena as linked to ecological system change (cf. Milkoreit et al. 2018). Based on our qualitative data, we address the following research questions (RQs):

1) How and why is the RM system in Finland approaching its tipping points (drivers of change; limits to adaptation)?

2) What kinds of qualitative system changes can be identified (impacts)?

3) Whether and how can potential negative consequences of crossing a tipping point be mitigated or prevented (incremental and transformative adaptation actions)?

4) What are the results of transformation (alternative states; even loss of livelihood)?

To operationalize the analysis, we first clarify the system identity by introducing the concept of RM in Finland. To answer the RQs 1-2, we examine the main drivers of change and the negative impacts thereof. To answer the RQs 3-4, we study how $\mathrm{RM}$ is adapting (incremental adaptation) and what kind of transformational adaptation would be needed to maintain the livelihood viable and avoid tipping into an alternative state where potential negative impacts or collapse appear. This study demonstrates how and why developments towards tipping points take place, what can be considered as alternative states and what does this transformation mean for RM in Finland as a whole.

Although this study focuses on RM in Finland, the approach is applicable to other regions where nature-based livelihoods are practiced in that they face some similar challenges, such as pastoral systems in, e.g., Sweden, Norway, Russia and Mongolia. This approach will be of interest to a wide range of scientists, administrators, decision-makers and local communities around the circumpolar North and beyond. To our knowledge, the present study is the first in-depth study analyzing the tipping phenomena of a pastoral system in the Arctic and, as such, addresses a significant research gap.

\section{Methods and data}

\section{Case study}

\section{Resource system, its users (actors), and units of reindeer management}

The RM system in the Nordic countries consists of RM actors, practices, and the traditional livelihood resources of reindeer herders: their pastoral systems and reindeer herds (see Käyhkö and Horstkotte 2017). The characteristics of RM in Finland (especially the "system identity"; Table 2) varies across the
RM area (Fig. 1). RM benefits from diversified and highquality pastures, i.e., ones that provide natural forage and peaceful grazing conditions (Forbes et al. 2006; Kitti et al. 2006; Colpaert and Kumpula 2012; Akujärvi et al. 2014). Seasonal habitat selection of reindeer is dependent on food biomass and availability (Jaakkola et al. 2006).

RM provides economic, ecological and cultural values for local communities (Reindeer Herders' Association 2021). Income is mainly derived from meat and tourism industry. RM keeps rural areas inhabited, provides culturally beneficial and meaningful employment for young people, and helps to reduce outmigration. Herding has been an important part of SESs for hundreds of years in northern Fennoscandia as regards kinship-based herd management units, or siidas. In Finland, ethnic Finns and Sámi both practice reindeer herding, whereas in Norway and Sweden, it is almost exclusively the right of Sámi. There are ca. 200,000 reindeer in Finland and ca. 5,000 reindeer owners, of which ca. 1,000 are indigenous Sámi. The total Sámi population in Finland is ca. 10,000 people (Sámediggi 2021). RM maintains important features of rural regions, such as pastoral landscapes and infrastructure related to reindeer herding such as fences and huts, as well as intangible assets of cultural heritage and tradition (Kumpula and Siitari 2020). The ecological value of RM is that reindeer grazing reduces tundra shrubification, which would otherwise decrease local and regional albedo and amplify climate warming (Horstkotte et al. 2017; Käyhkö and Horstkotte 2017). Large vertebrate herbivores such as reindeer can help to suppress the height and expansion of woody plants (Olofsson and Oksanen 2005; Olofsson et al. 2009; Speed et al. 2010; Normand et al. 2017; Cromsigt et al. 2018).

\section{Governance of reindeer management in Finland}

Based on the Reindeer Husbandry Act (848/1990), reindeer can graze freely, independent of land ownership, although they are semi-domesticated, privately owned animals. The RM area in Finland currently consists of 54 reindeer herding cooperatives (Fig. 1). They are members of the Reindeer Herders' Association, a governmental organisation which has a dual role both implementing government decisions and protecting the rights of herders. The RM area covers 122,936 $\mathrm{km}^{2}$, which comprises $36 \%$ of Finland's total land area (Reindeer Herders' Association 2021).

RM is governed at the national level by the Ministry of Agriculture and Forestry which is, for instance, responsible for decisions on the highest permitted number of living reindeer per herding cooperative. The reasons to control RM and set limitations to the highest permissible number of reindeer were driven by the needs of other land use, mainly agriculture and forestry, particularly after the Second World War and during times of rapid industrialization (Forbes et al. 2006; Heikkinen 2006). 
Table 2 Summary of the present-day characteristics of reindeer management in Finland divided into three main areas. Based on the literature review (Online resource 1). Classification by authors.

\begin{tabular}{llll}
\hline & Sámi ${ }^{1}$ homeland (north) & $\begin{array}{l}\text { Area specifically intended } \\
\text { for reindeer management (middle) }\end{array}$ & $\begin{array}{l}\text { Other reindeer } \\
\text { management area (south) }\end{array}$ \\
\hline $\begin{array}{l}\text { Drivers } \\
\text { Climate change }\end{array}$ & High impact & Moderate impact & Moderate impact \\
Land use change & Moderate impact & High impact & High impact \\
Governance & National, EU & National, EU & National, EU \\
System identity & & Fell, coniferous forest & Coniferous forest, mires \\
Main pasture types & Fell, mountain birch forest & Moderate & High \\
Predation pressure & High & Moderate & Low \\
Reindeer population size & High & Mixed & Mixed \\
Herder demography & Mixed & Common & Uncommon \\
Full-time herding & Common & Common & Some \\
Reindeer-based tourism & Some & Mainly Finnish & Mainly Finnish \\
Culture & Yes & Yes & Yes \\
Technical equipment in use & Possible & Limited & Limited \\
Pasture rotation & Some & Common & Common \\
Supplementary winter feeding & & &
\end{tabular}

${ }^{1}$ Note: In Finland, the Sámi have constitutional self-government regarding the Sámi languages and culture, which is managed by the Sámi Parliament and functions under the administrative sectors of the Ministry of Justice (Sámediggi 2021)

${ }^{2}$ Note: The Sámi homeland is officially part of the area specifically intended for reindeer management

The Regional Councils of Oulu and Lapland steer RM indirectly through strategic planning and regional zoning (Heikkinen 2006). Regional governmental authorities (ELY Centres for Economic Development, Transport and the
Environment) are responsible for the implementation of formal steering mechanisms. These are laws and regulations concerning RM and land use in the RM area set by the state, such as the Reindeer Husbandry Act (848/1990), together with municipal
Fig. 1 Reindeer herding cooperatives in Finland. The RM area can be divided into three main areas: 'the Sámi homeland' (north, above the red border), which officially also belongs to the 'area specifically intended for reindeer management' (middle, below the red border), and 'other reindeer management area' (south, below the blue border). The interviews were conducted in the cooperatives highlighted in grey. Design: Henri Wallen

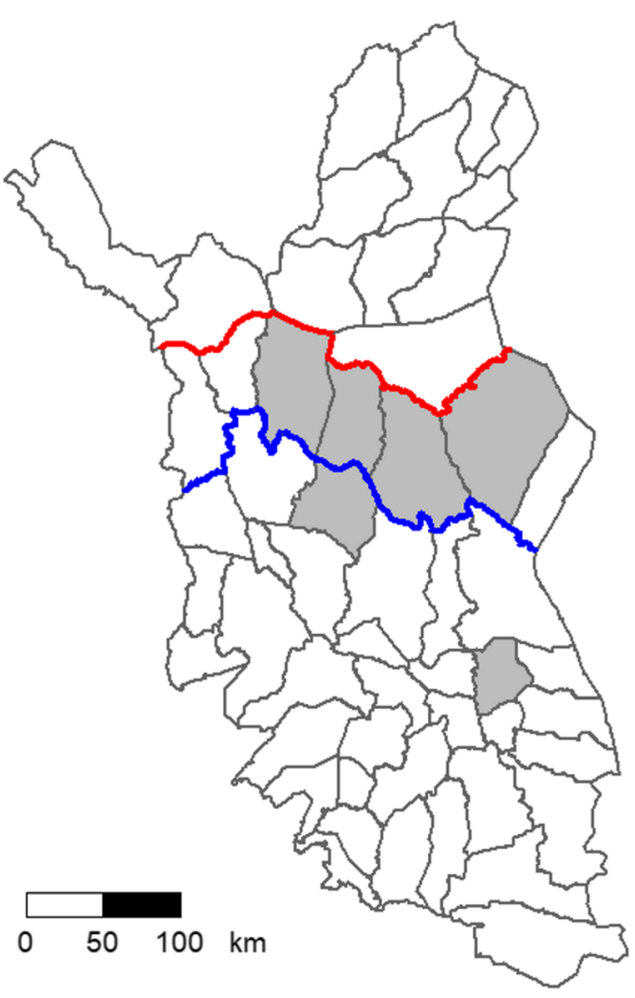


authorities for implementation of land use planning and nature conservation regulations (Heikkinen 2006).

The EU's agricultural and nature conservation policies strongly influence the RM system. The financial steering mechanisms include state and EU regulations (e.g., the total allowable number of animals), subsidies, and compensation regimes (e.g., for damage caused by predators).

\section{Data}

\section{Literature sample}

We examined a sample of scientific articles and book chapters on RM in Finland published in international peer-reviewed journals or books in English $(N=82$, published 2000-2018; see Online resource 1). This literature review is by no means exhaustive but covers key studies providing information on the resource system, indications on drivers of change, and discussion on alternative system states and tipping points from the past two decades. In the "Results: towards tipping points - drivers of change" section, we have used italics to mark several examples of how these terms have been defined or illustrated in the reviewed literature. The literature review provided data to respond to the research questions $1-4$.

\section{Semi-structured interviews with practitioners}

The interviews provided data to respond particularly to the research questions 1 and 2 . The lead author conducted semistructured interviews on-site with key practitioners $(N=9)$ in December 2016 in Northern Finland; heads of herding cooperatives and herders' advisors were invited by phone to share insights on their perceptions, views, and experiences on the changes. The purpose was to interview heads of cooperatives (poroisäntä) whose responsibility is to supervise the overall herding practices and administration of the cooperative and who thus have the most overall knowledge of the respective cooperatives they each represent. The interviewees were from the reindeer herding cooperatives that belong to the 'area specifically intended for reindeer management' (Kuivasalmi, Sattasniemi, Oraniemi and Kemin-Sompio) and 'other reindeer management area' (Syväjärvi, Tolva), covering altogether approximately $20 \%$ of the total RM area (Fig. 1). We selected cooperatives that are facing large-scale impacts of other land use (cf. Landauer and Komendantova 2018; Turunen et al. 2020) and climate change impacts (cf. Ruosteenoja et al. 2016; Table 2). In addition, the lead author also interviewed one elderly herder from one of the largest (i.e., land area, number of reindeer) herding cooperatives and two representatives of the Reindeer Herders'Association, who practice reindeer herding but also work as advisors for the whole RM area of Finland. The same interview data collection method was used by Landauer and Komendantova (2018), but in the present study, we used data based on a different set of interview questions:

- What kinds of reasons for changes do you see in the near and distant future, and how are the changes affecting this region?

- What do you see as potential limitations for reindeer herders to adapt to the changes?

\section{Data analysis}

From our data, we aimed to identify drivers of changes that 'push' this particular SES closer to tipping points that could potentially transform the system into an alternative state which can even precipitate loss of the livelihood. In our study, we also demonstrate what transformation means in practice and what kind of role adaptation plays in it. We have defined the reference point, the 'system identity' of RM (see Table 2), by examining what its ecological state, cultural characteristics and economic base are. To qualitatively assess whether a tipping point might be approaching or has already been crossed, we apply the 'Four criteria for defining collapse' of Cumming and Peterson (2017, p. 699).

We used the qualitative content analysis method (Neuendorf 2016) to analyze the data. Interview transcriptions and the full texts of the publications were coded in QSR International's NVivo qualitative analysis software. The map in Fig. 1 was executed by means of R (R Core Team 2020) and tmap (Tennekes 2018) programs.

\section{Results: towards tipping points-drivers of change}

\section{Overview of the drivers of change and need for adaptation}

We could identify three main drivers of change: (1) land use, (2) climate change, and (3) governance (Fig. 2; Online resource 1). These drivers affect both the resources of reindeer management SES (pastures, reindeer) and its users (herders). These, alone or in various combinations, can lead to economic, socio-cultural, and/or ecological tipping points, transforming the SES towards an alternative state; even loss of livelihood if adaptation is not possible. Financial and technological resources, as well as policy and governance mechanisms are needed to increase capacity to adapt within the system (see also Figs. 3, 4, and 5). Our case study provides examples of some of the elements potentially leading to collapse (cf. Cumming and Peterson 2017). 


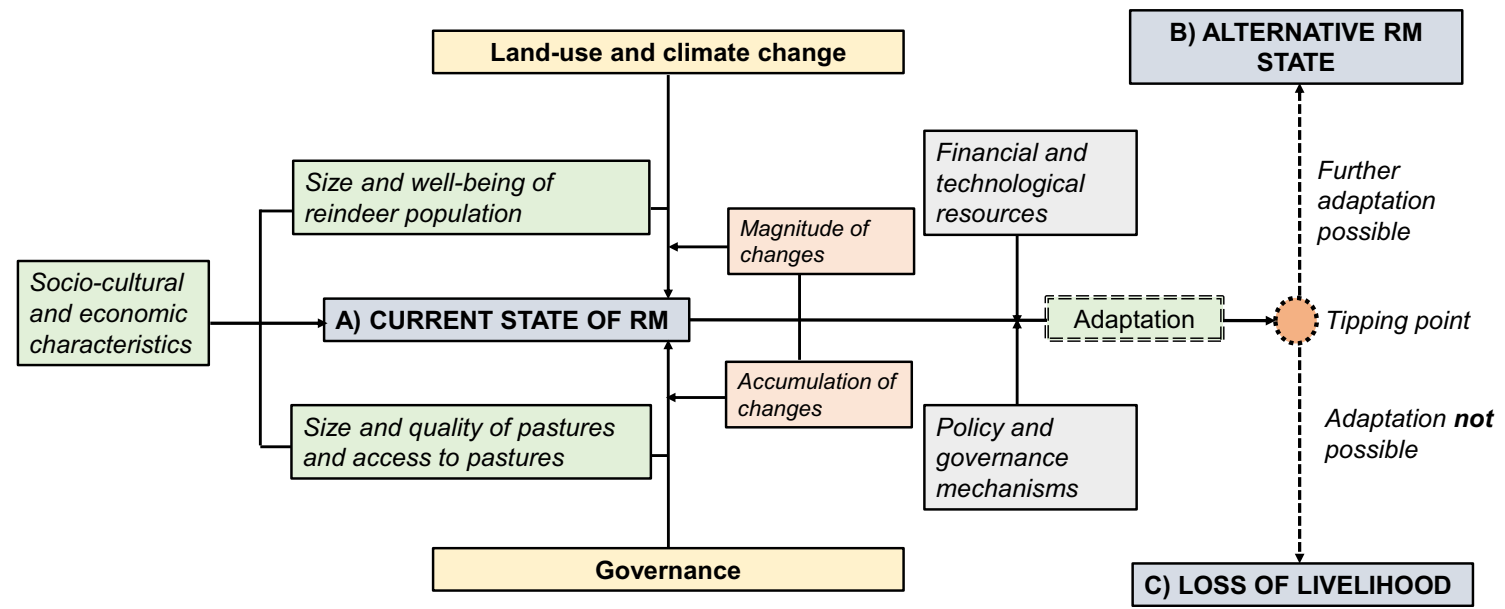

Fig. 2 Illustration of processes potentially driving the reindeer management system in Finland towards a tipping point: these drivers are land use and climate change, as well as governance. The magnitude of impacts and adaptive capacity depend on Financial and Technological resources (e.g., income, equipment) and on policy and governance mechanisms (e.g., subsidy and compensation policy, regulations) while

\section{Drivers and consequences of change in detail}

\section{Land-use change and related impacts}

Several studies have reported impacts caused by other land use in the RM area of Finland (see Online resource 1). Especially forestry and industrial infrastructure development are frequently mentioned in these studies. They cause rapid and often long-lasting, if not irreversible, changes in pasture resources and characteristics and lead to long-term impacts (cf. Cumming and Peterson 2017): less pastures, fragmented pastures, and reduced usability of pastures (Kumpula et al. 2007; Helle and Jaakkola 2008). Pape and Löffler (2012) use the term point of exceedance to refer to severe degradation they can influence the emergency of tipping points. The capacity to adapt delineates whether the system transforms either into an alternative (modified) state of reindeer management, or whether adaptation is not possible, and the reindeer management system is completely or locally lost (collapse)

of ecosystems, and Tahvonen et al. (2014) discuss potentially consequent reindeer population decline as collapse or crash. Degradation of lichens has critical consequences for RM (Turunen et al. 2009; Kivinen and Kumpula, 2014). Ground and arboreal (tree) lichen (Bryoria fuscescens, Alectoria sarmentosa) reserves of old-growth forests, which are crucial in maintaining the physical condition of reindeer through the winter, are decreasing (Jaakkola et al. 2013). Quality and availability of summer pastures are critical in terms of primary production because pregnant reindeer can suffer from poor summer forage availability or quality, which may affect calf production (Kumpula et al. 2002). Due to disturbances or lack of 'grazing peace' (e.g., due to predators), reindeer may avoid certain areas, or disperse across the area which makes herding

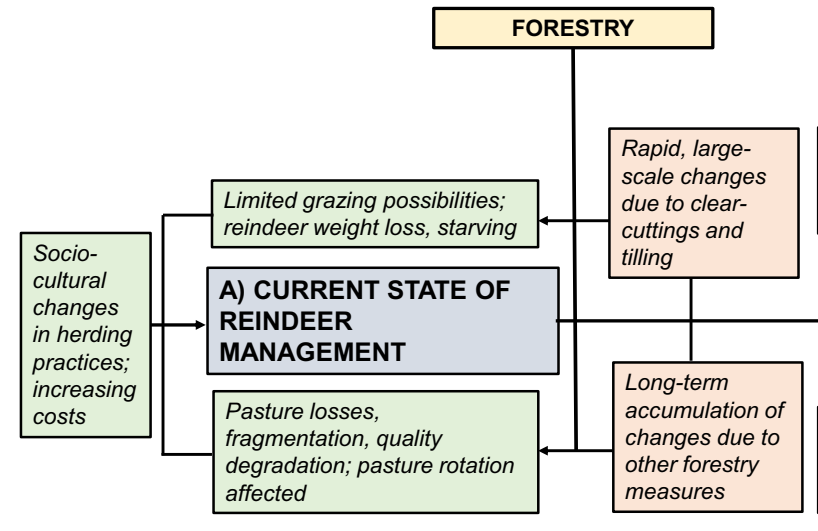

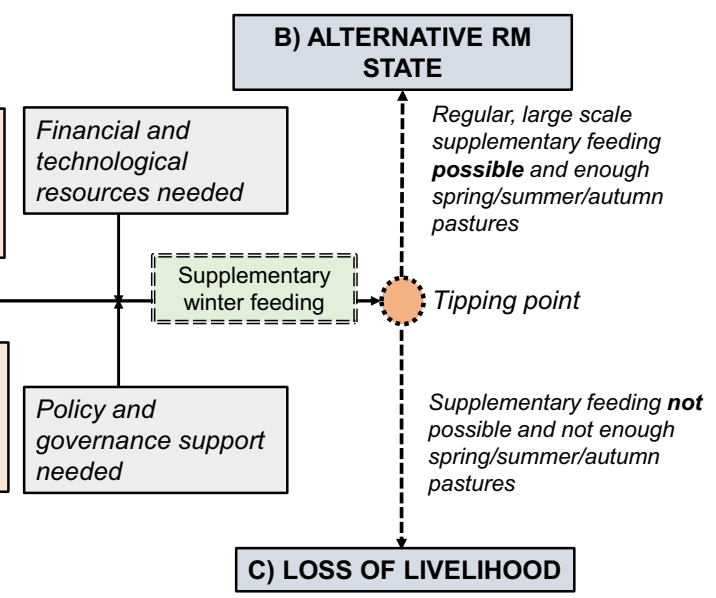

management in which regular and intensive supplementary winter feeding is practiced, or whether adaptation is not possible, and the reindeer management system is completely or locally lost (collapse)
Fig. 3 Illustration of land use (forestry) driven changes in reindeer management towards a tipping point. In this example, capacity to adapt by means of supplementary winter feeding delineates whether the system transforms either into an alternative (modified) state of reindeer 


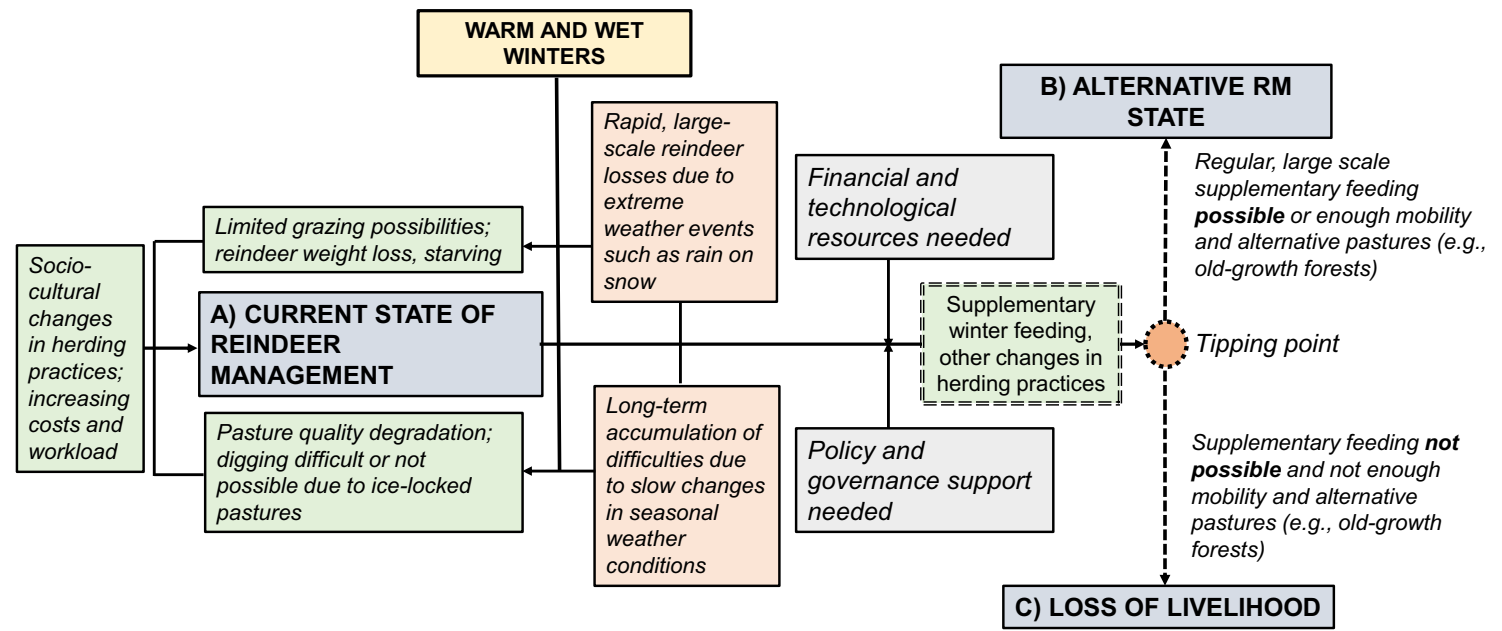

Fig. 4 Illustration of climate change-driven changes in reindeer management towards a tipping point. Also in this example, capacity to adapt by means of supplementary winter feeding delineates whether the system transforms either into an alternative (modified) state of reindeer

more difficult, time-consuming, and requires more labor, thus increasing costs (Kitti et al. 2006; Anttonen et al. 2011; Colpaert and Nykänen 2016). Seasonal pasture rotation may be hindered, and loss of peaceful pastures may also affect calving, leading to economic losses.

Conflicts between herders and other land users occur, and disturbances due to other land use are often irreversible and give rise to long-lasting impacts. For example, when a large open pit mine is abandoned once its operations are no longer profitable, it is not possible to resume natural pastures for RM on these lands (Kyllönen et al. 2006; Heikkinen et al. 2016). Industrial development can also increase risks of pollution which, in turn, might affect the image of reindeer meat as a delicacy and cause long-term economic impacts. Herders are the ones who carry both the risks and the costs of potential pollution incidents and land degradation. Due to the accumulation of impacts, a local ecological tipping point can be reached if pasture units become too small and fragmented and plant biomass suffers due to grazing and/or trampling pressure in remaining pastures (e.g., Kumpula et al. 2014; Tahvonen et al. 2014). The changes in pasture use through loss of flexibility within the landcape and fragmentation of pastures have been described as a regime shift (Horstkotte et al. 2014).

One prominent example where tipping point development and alternative system states clearly manifest themselves is the impact of intensive forestry on RM (see Fig. 3). Particularly clear-cuts can cause rapid changes and impacts that last over generations. Furthermore, gradual but successive forestry actions also lead to short and long-term local and regional impacts on RM resources and its users: deterioration of the quantity and quality of the pastures, fragmentation, and especially strong disturbance on critical winter pastures (cf. Horstkotte et al. 2011; Kumpula et al. 2014; Turunen et al. 2020). Reindeer tend to avoid dense, young forests and prefer old- management in which regular and intensive supplementary winter feeding is practiced, or whether adaptation is not possible, and the reindeer management system is completely or locally lost (collapse).

growth forests, because the latter provide a critical energy source in winter via the aforementioned arboreal lichens. The availability of winter forage has been decreasing significantly over many decades, leading to difficulties in herding (e.g., reduced flexibility and mobility in pasture use) in the majority of the RM area in Finland and demand for supplementary fodder (Helle and Jaakkola 2008; Kumpula et al. 2014). This has resulted in an alternative system state with regular winter feeding in most of the reindeer cooperatives in Finland since the 1970s (Helle and Jaakkola 2008): for $\mathrm{RM}$ to continue, a radical shift in herding practices by means of regular intensive supplementary feeding as a "repairing" mechanism has become necessary to avoid irreversible impacts (Fig. 3). Rapid losses in available fodder resources due to forestry provide a good example of one element of collapse development described in Cumming and Peterson (2017) that might lead to collapse due to distinct changes in the system identity (Table 2).

Also, the interviewed herders raised concerns about the current impacts and future risks of other forms of land use, in particular forestry. They see an ecological tipping point approaching, due to substantial losses in the system identity and capital (cf. Cumming and Peterson 2017), especially due to a range of cumulative impacts:

“...in this area we have about $900 \mathrm{~km}$ of snowmobile trails, a mine, wind farms, husky safaris, and all kinds of other land use. And at the same time Metsähallitus [state owned forest enterprise] is logging so much! There are no protected [old-growth] spruce forests available for reindeer anymore. “

Herder \#1

"Forestry has massive impacts. It has reduced the quality of pastures. Now they will build very large bioenergy 


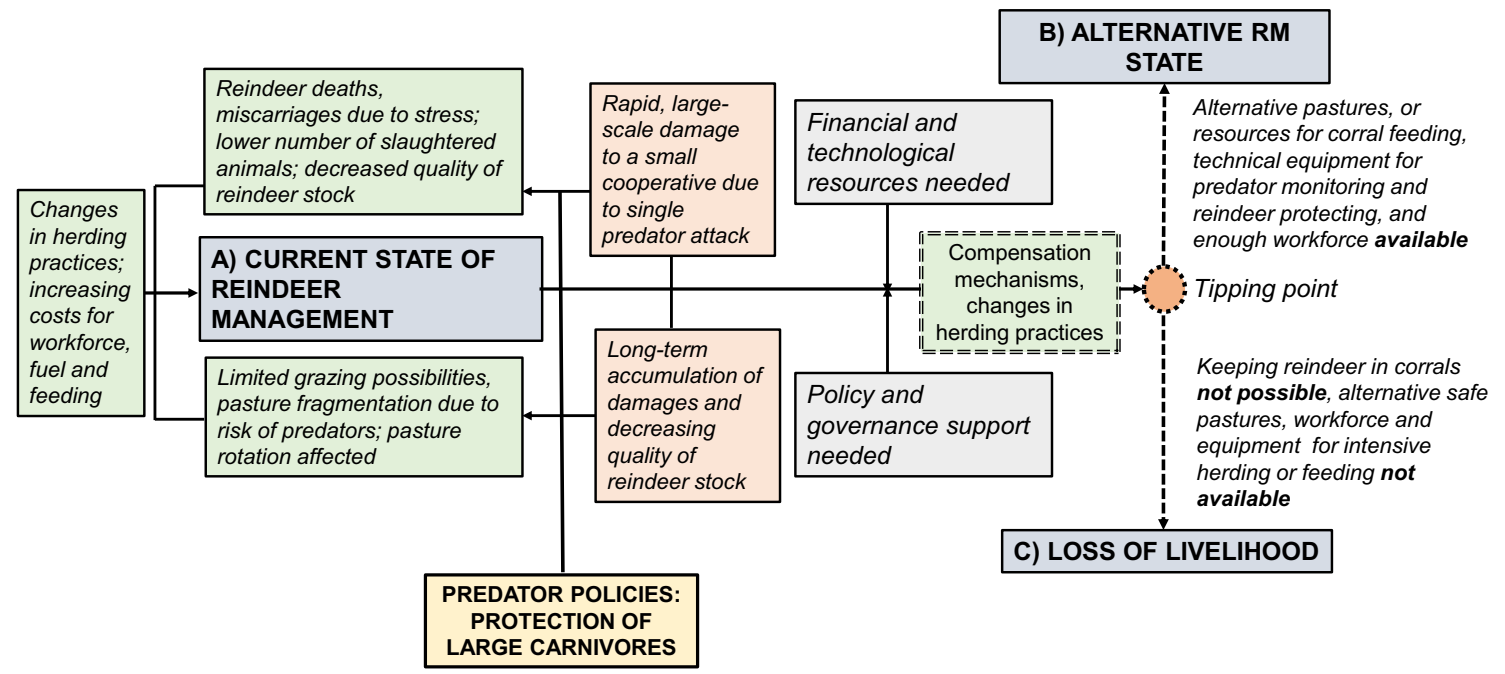

Fig. 5 Illustration of governance-driven (predator policies) changes in reindeer management towards a tipping point. In this example, capacity to adapt by means of compensation mechanisms delineates whether the

plants, but where are they going to get that wood? If from the old-growth forests, which are the last arboreal lichen resources for reindeer, then we have to give up on herding! “

Herder \#2

"They have been logging everywhere. There is no lichen anymore! It is gone. We could only keep about 500 reindeer if they were left on their own. They would starve in January without supplementary feeding."

Herder \#3

Supplementary feeding requires more time, workforce, and money. For financial reasons - an economic tipping point - in particular, large-scale supplementary feeding is not always possible, only emergency feeding (Turunen and VuojalaMagga 2014).

\section{Climate change and related impacts}

Climate change affects RM in Finland in many ways and it has been studied widely since 2003 (Online resource 1; see e.g., Lépy and Pasanen 2017; Vuojala-Magga et al. 2011; Turunen et al. 2016; Forbes et al. 2020). Intensification of agroforestry practices and expansion of forests are expected, as well as changes in the quality, biomass, and plant species composition of reindeer forage (Forbes et al. 2006; Turunen et al. 2009). Warmer and wetter winters heighten the risk of mould formation on the pastures, which renders subnivean lichens inedible (Kumpula et al. 2000). It is also likely that ice encrusted snow cover becomes more frequent in winter, which limits the possibilities for reindeer to dig for lichen (Rasmus et al. 2018, 2020). Often, neither old-growth forests with arboreal lichen nor supplementary feeding as an alternative management state are available (Fig. 4). In such cases, high energy demands system transforms either into an alternative (modified) state, or whether adaptation is not possible, and the reindeer management system is completely or locally lost (collapse)

associated with digging, coupled with poor forage availability, affect the physical condition of reindeer and can lead to starvation (Kumpula and Colpaert 2009). This was highlighted by the herders.

Climate change can affect reindeer health, too (Online resource 1). Warmer summers with increased precipitation may lead to more severe insect harassment and more frequent parasite epidemics in the long term (Laaksonen et al. 2009, 2010; Nikander et al. 2007; Riseth et al. 2018). All of these factors affect reindeer population - the ecological capital - its size, fitness, and behavior. Due to a rapid increase in parasite populations, an ecological tipping point may be approaching, as stated by Laaksonen et al. (2010). The interviewed herders reported rapid spreading of diseases and parasites, and perceived infections as a potential consequence of climate change:

"The occurrence of diseases has increased. I have the feeling that there is an expansion of the deer population in this area. It has been said that they carry parasites... If these parasites become more common, reindeer might have miscarriages; they might lose their calves."

Herder \#3

"I do not know why but nowadays summers have become very rainy and humid... We have noticed that calves have more eye infections and other infections."

Herder \#4

\section{National and EU governance and related impacts}

Governance as a driver of change and related impacts has been a focus of several studies (Online resource 1). Change from the nomadic subsistence economy to the subsidized market 
economy marked a significant shift in the nature of RM in Finland since WWII (Burkhard and Müller 2008). More recently, the national governance of RM has further transformed the livelihood towards more stationary herding, subject to incressingly strict agricultural norms (Forbes et al. 2006). Recent policies have geared RM towards a profit-oriented meat production industry, especially since Finland joined the EU in 1995, and so adhering to the EU's agricultural policy goals. This has resulted in an alternative state of RM in northern Fennoscandia: the number of herders and herding families has decreased, while herding has become more centralized. This transformation has partially affected the collective nature of RM (Heikkinen 2006; Turunen et al. 2016). Modern livestock management practices have replaced some of the traditional ones (Colpaert and Nykänen 2016). According to Burkhard and Müller (2008), especially Sámi herders have raised concerns about their social welfare and ethnic identity because they feel that the "agricultural-like" reindeer business, an alternative management state, might take over pastoral self-employment type of herding (Dana and Light 2011; see Table 2). They also fear that traditional ways of knowing (cf. Forbes et al. 2020) and socio-cultural identity could be lost in the process (cf. Cumming and Peterson 2017; see also Lépy et al. 2018).

The current top-down decision-making structure within RM governance limits herders' power to self-determine the number of reindeer based on traditional and local ways of knowing and to ensure an adequate volume of meat production during years when pasture conditions are deemed good. Examples include increasing the number of reindeer on demand, such as when predator losses are high, or when market prices of reindeer meat fluctuate. The quotation below describes how important it would be for herders to be able to make independent decisions concerning their livelihood, to respond and adapt to varying pasture conditions based on their own knowledge instead of top-down governance. The relative power imbalance becomes evident when herders have no formal say, and their expertise is not always taken into account (Landauer and Komendantova 2018; Harkoma and Forbes 2020). Lack of self-determination and equity in decision-making power can cause a risk of economic tipping that might even lead to loss of the system locally (see also Kyllönen et al. 2006):

"Our summer pastures are very good, so we could get lots of calves in autumn and the calving weight would be high ... if we could increase the number of reindeer. This would mean financial income for us if meat prices were good. If prices went down there is a risk that herding in this area could be lost."

Herder \#3

The state can support RM by providing subsidies (Ministry of Agriculture and Forestry) and compensation schemes (Ministry of the Environment) or by introducing policies that help increase profitability and diversification of the livelihood (Heikkinen et al. 2010; Pekkarinen et al. 2015). A herder owning at least 80 reindeer is eligible for subsidies. This is based on the EU's agricultural policy aiming at lowering production costs and increasing meat production while also enhancing possibilities for full-time herding. However, smallscale herders are not subsidized (Kietäväinen and Tuulentie 2018) and thus the profitability of their livelihood remains low (Turunen et al. 2016), while the large-scale herders with the most reindeer have already reached the total allowable quota of reindeer within the cooperative (Laakso 2008). Small-scale herders might end up in a situation in which they are forced to give up on herding due to the increasing costs and the requirement to expand meat production, and yet being unable to expand their activities in order to make profit (Heikkinen 2007).

The EU's nature conservation policy aims at protecting large carnivores due to international conservation pressures (Heikkinen et al. 2011) and need to protect endangered species. This has changed the nature of RM in Sweden and Finland over several decades (Beach 2004; Heikkinen et al. 2010; Vuojala-Magga 2012). Coping with predators has led to changes in herding practices, among them avoidance of certain pastures, as well as imposed a physical and mental burden for herders. High predation pressure lowers the calving success of reindeer and the number of slaughtered animals; the material basis of the livelihood (Turunen et al. 2017). The presence of an increasing number of large carnivores is making RM in some areas unprofitable and leads to situations in which compensation for damage or finding sources of additional employment have been needed to tackle the uncertainty and ensure regular income (e.g., Müller-Wille et al. 2006; Heikkinen et al. 2011; see Fig. 5).

According to Vuojala-Magga (2012), in particular young Sámi herders have concerns about their future because the strong increase in the number of predators threatens the entire livelihood. Also, our interviewees reported having experienced an increased presence of predators and how it increases their workload. As herders have limited control over predators, it seems that, at least in some areas, a tipping point - in this context also called a critical threshold by Vuojala-Magga (2012) — will be reached very soon since the herders report that predator-caused losses are increasing:

"In the past, we could find only a few tracks of predators. We never picked up the carcasses because there were not so many that it would have made sense. Nowadays, if you see a wolverine, for example, you have to take your snowmobile and follow the tracks because you will find dozens of carcasses!

Herder \#1

In some herding cooperatives, supra-national conservational goals, seen through the EU and national predator policies, 
have changed the priorities of RM from herding reindeer into monitoring predator-caused losses (required for compensation). Thus, a herder or group of herders may be forced to give up their livelihood (described as loss by Vuojala-Magga and Turunen 2015). In such cases, a transformation into an alternative management state has taken place (Table 2). In some areas, more effort ends up being allocated to finding carcasses in order to receive due compensation than time is available for actual herding practices (Heikkinen et al. 2011).

\section{Socio-cultural implications of transformation}

Escalation of conflicts with other land users or severe predation may serve to deter young herders from choosing herding as their livelihood and pressure them to search for alternative employment. Intra- and intergenerational changes, such as aging of herders and outmigration due to reduced income sources, contribute to the uncertainty of the future of young herders. This development could mark a demographic tipping point, and in the alternative state, there would be fewer young herders and more elderly herders. Furthermore, more centralized reindeer herding "meat industry" with larger herds but fewer full-time herders could be the alternative state. With a smaller number of herders, the herding work becomes more difficult, and if there is a smaller number of animals slaughtered, it becomes harder to gain enough economic profit from herding (see also Table 2). These cultural transformations towards substantially different livelihood systems were described as flipping over threshold by Lépy et al. (2018). Along the path, there may be alienation from, and substantial losses of, tradition and culture (Heikkinen 2006, 2007): it becomes more difficult to pass the traditional knowledge on to younger generations. If the changes are long term, large scale, and irreversible, the livelihood might be lost (an alternative state appearing as "collapse", cf. Cumming and Peterson 2017).

\section{Adaptation and its limits}

\section{The role of financial and technological resources}

The role of adaptation is to avoid rapid changes or reduce substantial losses and by so doing, try to maintain economic, socio-cultural, or ecological identity also in the long term. As an incremental adaptation option to land-use changes, the herders can move reindeer to alternative pastures (if available) or apply new pasture rotation methods (if applicable) (Horstkotte et al. 2017). Incremental adaptation to detrimental weather conditions and climate-related risks include, for example, using parasite treatments, rescheduling work, practicing supplementary feeding, as well as modifying herding practices; moving reindeer to alternative pastures or applying new pasture rotation methods (Turunen et al. 2016; Horstkotte et al. 2017; Rasmus et al. 2020). Early slaughtering of calves, more intensive shepherding to protect herds from predators, feeding in corrals, use of GPS-collars to follow reindeer movements, and avoiding certain pastures are examples of incremental adaptation options to increasing predation pressure in RM (see, e.g., Axelsson Linkowski et al. 2017; Turunen et al. 2017).

Since the 1960s, technological development and mechanization have helped the herders adapt to some of the changes that have been taking place. An example of this is what has been referred to as "the snowmobile revolution" in the 1960 s (Pelto et al. 1968; Helle and Jaakkola 2008). The snowmobile was introduced because it saves the herders time and effort and allows for the tasks to be completed with less workforce. Thus, the introduction of the snowmobile and other technical equipment ${ }^{2}$ has developed herding and helped the livelihood to adapt, or brought it across a tipping point into an alternative state. In any case, it has increased the costs of RM (Helle and Jaakkola 2008; Turunen et al. 2016). Furthermore, manpower and collaboration are still needed especially during the roundups and calf marking.

Limit to adaptation may show itself as shortage of technological or financial resources (Löf 2013). Financial capacity and steady revenues to be able to adapt to the changes in the livelihood become very critical in the circumstances where various drivers of change are causing impacts that are accumulating over time and space. In order to secure a steady income, herders have to be increasingly involved in parttime jobs outside the reindeer sector or consider economic diversification (Dana and Riseth 2011; Heikkinen et al. 2007). Investments are required for technical equipment and gasoline, supplementary fodder, and additional periodic workforce are needed to be able to continue herding and safeguard economic returns (Lee et al. 2000; Heikkinen 2006).

\section{Policy and governance mechanisms - towards transformational adaptation?}

Also governance-related factors can lead to meeting the limit to adaptation: there may be unsuitable or missing governance mechanisms such as financial- and market-based steering to support herders (Löf 2013). Transformational adaptation in RM requires government support because it requires innovations, and for these, financial support is needed. Economic concerns seem to be among the most limiting factors for the herder's ability to adapt to change, so financial support (e.g., government subsidies) would be needed if land-use change further decreases the quantity and quality of pastures. One example is need to develop supplementary winter feeding, nowadays a common practice in RM in Finland. No matter

\footnotetext{
${ }^{2}$ More modern measures include technical aids for locating herds and finding reindeer damage, e.g., the use of GPS collars and mortality transmitters.
} 
how necessary and useful, there are also negative impacts of supplementary feeding on pastures, and feeding alone would not secure long-term economic profits (Pekkarinen et al. 2015). Furthermore, there are risk of diseases involved, and reindeer becoming tame and more dependent on herders (Turunen and Vuojala-Magga 2014). This is how one of our interviewees perceives an economic tipping point which, in this case, is determined by financial capacity to implement supplementary feeding and workforce if the amount of oldgrowth forests continues to decrease due to other land use:

"It would be extremely costly to feed our 8,000-9,000 reindeer in this area, and it would also require additional workforce. But if there are no arboreal lichen pastures, we have to feed our reindeer. Reindeer have difficulties with digging in very harsh conditions when there is icy snow cover. Arboreal lichen is the only natural forage in winter. If it disappears, we will reach a critical point in reindeer management in this area."

Herder \#2

Furthermore, although government subsidies can support intensification of production and revenues (e.g., Pekkarinen et al. 2015) and hence support transformative adaptation, they also tend to pull down producer prices, as net income is stalled (Heikkinen et al. 2007). To ensure high productivity of reindeer stock, the proportion of slaughtered reindeer in good condition should remain rather constant (Kumpula et al. 2002). In the constantly growing global market, it is difficult for this subsistence livelihood to compete with other economic sectors even if herders rationalize their business into a "meat-packing industry", an alternative state (Dana and Dana 2007). Even though an increasing number of part-time herders may be seen as unwanted development, even pushing the system across a tipping point into an alternative state, economic diversification can help herders gain income from other sources if income from RM is temporally limited (e.g., due to low meat prices in the market) (see Heikkinen 2006; Dana and Riseth 2011).

To avoid potential loss of the livelihood, institutional support by government to transformative adaptation via other means than financial subsidies alone is needed. Supporting transformational adaptation of RM may mean empowering the herding cooperatives, allowing self-regulation whenever possible, institutional support to learning and increasing societal awareness on RM, and discussing the acceptability of certain adaptation actions. For instance, fundamental changes in certain herding practices may be perceived by herders as loss of the system identity (Table 2); crossing the tipping point. This may appear as unwillingness to adapt (cf. Löf 2013).

Supporting transformational adaptation may also mean radical changes on a wider societal level. Adaptation options of herders are often very limited due to needs of other land users within the landscape (Kumpula et al. 2007; Pape and Löffler
2012; Eira et al. 2018). Planning any new pasture rotation schemes should be done in collaboration with other land users. Suitable governance tools may not be available, and if they are, there may be power imbalances (Löf 2013; Landauer and Komendantova 2018). Adaptive co-management of the commonly used landscapes is called for (cf. Berkes 2010).

\section{Discussion and conclusions}

Based on a literature review and interviews with key practitioners, this study reveals three main drivers of change that push the social-ecological system of reindeer management in Finland closer to tipping points; gear it towards alternative system states, which may even appear as loss of the livelihood. The drivers we identified in this study are (1) land-use-related driver as demonstrated by the example of forestry; (2) climate-change-related driver as exemplified by warm and wet winters; and (3) governance-related driver as illustrated by the EU large carnivore protection policy. Whether, when and how the system will reach one of its tipping points; transform into an alternative state, even collapse, depends on the magnitude, time, and location of the impacts and potential loss of the system identity (Cumming and Peterson 2017) and the available adaptation mechanismsincremental or transformational (Lonsdale et al. 2015). Limits to adaptation in RM are often associated with lack of time (workforce), space (pastures), money (income, compensation), and decision-making (lack of power or policy and governance support). Regarding the alternative system states, for some herders, RM becoming a "meat-processing industry" means more centralized herding practices, fewer herders but more reindeer and full-time business and higher income, whereas to others it means a need to diversify the business and transition to herding as a parttime job. Some consider that adopting intensive supplementary feeding is, in itself, an indication of an alternative state of RM because the traditional flexibility in pasture use, or pasture rotation, is limited or impossible due to other forms of land use or climatic changes. In some herding cooperatives, an economic tipping point is reached if predation compensation is insufficient. Some consider that the reliance of the RM system on compensatory mechanisms is so different from the traditional state of the system that the system can be said to have reached an alternative state. As the changes and the risks associated with them accumulate, irreversible impacts on RM, especially in the long-term, can be expected (cf. Cumming and Peterson 2017). This might particularly affect the interest of young generations in continuing the livelihood and, in the worst case, lead to loss of RM in Finland.

Top-down governance (e.g., setting the highest permissible number of reindeer by state) and lack of self-determination (e.g., not having the possibility to make decisions on reindeer population size or pasture use based on practitioner knowledge) limit the herders' adaptive capacity and, sometimes, their willingness to adapt. However, it is important to 
understand that also the herders' perceptions of suitable adaptation strategies and the limits to adaptation tend to vary. These perceptions and preferences depend, to some extent, on the available resources and the herders' preparedness to change RM practices, which can have regional differences.

There clearly are at least two sides in every story. For example, there are conflicts between reindeer herding and nature conservation regarding certain predator species, and between reindeer herding and forestry (Heikkinen et al. 2011; 2012a, b; Turunen et al. 2020). In our study focusing on RM, some of the environmental and societal changes (e.g., warming climate, forestry, industrial infrastructure development, predator conservation) were perceived by herders as pressures and problems. Elsewhere, they may be considered positive - as development, success, and beneficial for society. Our SES approach shows that what is positive development for one livelihood or land user may constitute a driver towards tipping points for the other. This raises an important point on social justice, as well as rights and responsibilities; who has the right to decide what constitutes a desirable system state? Can we let RM, a traditional livelihood important for Arctic local communities, "flip over threshold" or "collapse"? Or should we rather make sure, in a collaboratory manner, that large negative impacts on the livelihood can be prevented?

In this study, we did not assess tipping points quantitatively, but instead relied on a qualitative analysis by means of data triangulation of interviews and scientific literature, being aware of some weaknesses of the qualitative approach to examining tipping points (cf. Milkoreit et al. 2018). However, we argue that a qualitative analysis with empirical data gives a more holistic picture of the drivers of change affecting RM in Finland, which can inform policy in more depth than a detailed quantitative analysis of an isolated feature of RM. In the future, a review of the large amount of grey literature relevant to the subject in the context of Finland would be beneficial to complement the scientific peer-reviewed literature review conducted in this study, and the terminology and definitions around tipping points presented here.

In particular, the biogeographical differences and regional characteristics of RM areas such as varying pasture resourcesforest pastures, fell pastures and mires - and land use pressure across the region must be understood to identify and understand the relevant tipping points and their role in the transformation of the RM system. Since this study was about RM in Finland only, the regional differences across Fennoscandia would need further investigation. The impacts of transformation are likely to vary depending on the region, as they do even within Finland, as land use pressure, the mode and type of governance, the length of winter, the heterogeneity and quality of pastures, the cultural and economic value of reindeer, the local history and culture of each area, and the size of herding cooperatives vary. More systematic research on the types of cumulative changes would be needed. For example, in order to be able to estimate impact severity, it might be useful to examine whether the changes taking place are linear or abrupt and to study their magnitude. Scenarios of potential alternative stable states could be developed because forward-looking assessments and monitoring of changes could provide information in particular on the cumulative drivers of change and potential negative impacts of transformation. This could also inform adaptation planning of pastoral systems in other parts of the world.

Supplementary Information The online version contains supplementary material available at https://doi.org/10.1007/s10113-021-01757-3.

Acknowledgments This study was supported by the Nordic Centre of Excellence in Arctic Research 'Reindeer Husbandry in a Globalizing North' (ReiGN) funded by NordForsk. We would like to thank the interviewees for their time and contribution. Special thanks to Dr. Minna Turunen and the two anonymous reviewers for the very constructive feedback, Henri Wallen for technical support and Sari Kokkola for English language support.

Funding Open access funding provided by University of Lapland.

Open Access This article is licensed under a Creative Commons Attribution 4.0 International License, which permits use, sharing, adaptation, distribution and reproduction in any medium or format, as long as you give appropriate credit to the original author(s) and the source, provide a link to the Creative Commons licence, and indicate if changes were made. The images or other third party material in this article are included in the article's Creative Commons licence, unless indicated otherwise in a credit line to the material. If material is not included in the article's Creative Commons licence and your intended use is not permitted by statutory regulation or exceeds the permitted use, you will need to obtain permission directly from the copyright holder. To view a copy of this licence, visit http://creativecommons.org/licenses/by/4.0/.

\section{References}

Axelsson Linkowski W, Kvarnström M, Westin A, Moen J, Östlund L (2017) Wolf and bear depredation on livestock in Northern Sweden 1827-2014: Combining history, ecology and interviews. Land 6:63. https://doi.org/10.3390/land6030063

Akujärvi A, Hallikainen V, Hyppönen, M, Mattila E, Mikkola K, Rautio P (2014) Effects of reindeer grazing and forestry on ground lichens in Finnish Lapland. Silva Fenn 48: 1-18. https://doi.org/10.14214/sf. 1153

Anttonen M, Kumpula J, Colpaert A (2011) Range selection by semidomesticated reindeer (Rangifer tarandus tarandus) in relation to infrastructure and human activity in the boreal forest environment, northern Finland. Arctic:1-14. https://doi.org/10.14430/arctic4075

Beach H (2004) Political ecology in Swedish Saamiland'. In: Anderson D, Nuttall M (eds) Cultivating Arctic landscapes: knowing and managing animals in the circumpolar North. Berghahn Books, Oxford

Berkes F (2010) Adaptive co-management and complexity: exploring the many faces of co-management. In: Armitage D, Berkes F, Doubleday N (eds) Adaptive co-management: collaboration, learning, and multi-level governance. UBC Press, Vancouver, pp 19-37

Buchanan A, Reed MG, Lidestav G (2016) What's counted as a reindeer herder? Gender and the adaptive capacity of Sami reindeer herding communities in Sweden. Ambio 45:352-362. https://doi.org/10. 1007/s13280-016-0834-1 
Burkhard B, Müller F (2008) Indicating human-environmental system properties: case study northern Fenno-Scandinavian reindeer herding. Ecol Indic 8:828-840. https://doi.org/10.1016/j.ecolind. 2007.06.003

Colpaert A, Kumpula J (2012) Detecting changes in the state of reindeer pastures in northernmost Finland, 1995-2005. Polar Rec 48:74-82. https://doi.org/10.1017/S0032247411000581

Colpaert A, Nykänen J (2016) GPS-collar tracking and GEO-spatial modelling to analyze the effects of hydro-power development on reindeer herding in Northern Finland. Вестник СанктПетербургского университета Науки о Земле 3:90-105. https:// doi.org/10.21638/11701/spbu07.2016.307

Cromsigt JP, te Beest M, Kerley GI, Landman M, le Roux E et al (2018) Trophic rewilding as a climate change mitigation strategy? Philos T R Soc B 373:20170440. https://doi.org/10.1098/rstb.2017.0440

Cumming GS, Peterson GD (2017) Unifying research on social-ecological resilience and collapse. Trends Ecol Evol 32:695-713. https:// doi.org/10.1016/j.tree.2017.06.014

Dana LP, Light I (2011) Two forms of community entrepreneurship in Finland: are there differences between Finnish and Sámi reindeer husbandry entrepreneurs? Entrepreneurship Reg Dev 23:331-352. https://doi.org/10.1080/08985626.2011.580163

Dana LP, Dana TE (2007) How do self-employed Sami people perceive the impact of the EU and globalisation? Int J Business Glob 1:3-19 http://www.jstor.org/stable/40513049. Accessed 18 Feb 2021

Dana LP, Riseth ÅJ (2011) Reindeer herders in Finland: Pulled to community-based entrepreneurship and pushed to individualistic firms. Polar J 1:108-123. https://doi.org/10.1080/2154896X.2011.568795

Dow K, Berkhout F, Preston BL, Klein RJ, Midgley G et al (2013) Limits to adaptation. Nat Clim Chang 3:305. https://doi.org/10.1038/nclimate1847

Eira IMG, Oskal A, Hanssen-Bauer I, Mathiesen SD (2018) Snow cover and the loss of traditional indigenous knowledge. Nat Clim Change 8:924-936. https://doi.org/10.1038/s41558-018-0319-2

Endicott E (2012) A history of land use in Mongolia: the thirteenth century to the present. Pagrave Macmillan, New York

Forbes BC, Bölter M, Müller-Wille L, Hukkinen J, Müller F, et al. (2006) Reindeer management in northernmost Europe: linking practical and scientific knowledge in social-ecological systems. Ecol Stud 184. Springer, Berlin Heidelberg

Forbes BC (2013) Cultural resilience of social-ecological systems in the Nenets and Yamal-Nenets Autonomous Okrugs, Russia: A focus on reindeer nomads of the tundra. Ecol Soc 18:36. https://doi.org/10. 5751/ES-05791-180436

Forbes BC, Kumpula T, Meschtyb N, Laptander R, Macias-Fauria M et al (2016) Sea ice, rain-on-snow and tundra reindeer nomadism in Arctic Russia. Biol Lett 12:20160466. https://doi.org/10.1098/rsbl.2016.0466

Forbes BC, Turunen MT, Soppela P, Rasmus S, Vuojala-Magga T, Kitti $\mathrm{H}$ (2020) Changes in mountain birch forests and reindeer management: comparing different knowledge systems in Sápmi, northern Fennoscandia. Polar Rec 55:507-521. https://doi.org/10.1017/ S0032247419000834

Harkoma A, Forbes BC (2020) Traditional reindeer rangeland management and a (human) rights-based approach to food sovereignty. In: Hossain K, Nilsson L, Herrmann T (eds) Food Security in the High North. Routledge, London. https://doi.org/10.4324/9781003057758

Heikkinen HI (2006) Neo-entrepreneurship as an adaptation model of reindeer herding in Finland. Nomadic Peoples 10:187-208. https:// doi.org/10.3167/np.2006.100211

Heikkinen HI (2007) Changing business strategies of reindeer husbandry in Finland. Int J Business Perf Manage 9:301-326. https://doi.org/ 10.1504/IJBPM.2007.013313

Heikkinen HI, Lakomäki S, Baldridge J (2007) The dimensions of sustainability and the neo-entrepreneurial adaptation strategies in reindeer herding in Finland. J Ecol Anthropol 11:25-42. https://doi.org/ $10.5038 / 2162-4593.11 .1 .2$
Heikkinen HI, Sarkki S, Jokinen M, Fornander DE (2010) Global area conservation ideals versus the local realities of reindeer herding in northernmost Finland. Int J Business Glob 4:110-130. https://doi. org/10.1504/IJBG.2010.030665

Heikkinen HI, Moilanen O, Nuttall M, Sarkki S (2011) Managing predators, managing reindeer: contested conceptions of predator policies in Finland's southeast reindeer herding area. Polar Rec 47:218-230. https://doi.org/10.1017/S0032247410000513

Heikkinen HI, Kasanen M, Lépy É (2012a) Resilience, vulnerability and adaptation in reindeer herding communities in the Finnish-Swedish border area. Nord Geogr Publ 41:107-121 https://nordia.journal.fi/ article/view/66058. Accessed 18 Feb 2021

Heikkinen HI, Sarkki S, Nuttall M (2012b) Users or producers of ecosystem services? A scenario exercise for integrating conservation and reindeer herding in northeast Finland. Pastoralism: Research, Policy and Practice 2:11. https://doi.org/10.1186/2041-7136-2-11

Heikkinen HI, Lépy É, Sarkki S, Komu T (2016) Challenges in acquiring a social licence to mine in the globalising Arctic. Polar Rec 52:399 411. https://doi.org/10.1017/S0032247413000843

Helle TP, Jaakkola LM (2008) Transitions in herd management of semidomesticated reindeer in northern Finland. Ann Zool Fennici Finnish Zoological and Botanical Publishing Board, In, pp 81-10. https://doi.org/10.5735/086.045.0201

Horstkotte T, Moen J, Lämås T, Helle T (2011) The legacy of loggingestimating arboreal lichen occurrence in a boreal multiple-use landscape on a two century scale. PloS one 6, e28779. https://journals. plos.org/plosone/article?id=10.1371/journal.pone. 0028779

Horstkotte T, Sandström C, Moen J (2014) Exploring the multiple use of boreal landscapes in northern Sweden: the importance of socialecological diversity for mobility and flexibility. Hum Ecol 42: 671-682. https://doi.org/10.1007/s10745-014-9687-z

Horstkotte T, Utsi TA, Larsson-Blind Å, Burgess P, Johansen B et al (2017) Human-animal agency in reindeer management: Sámi herders' perspectives on vegetation dynamics under climate change. Ecosphere 8:e01931. https://doi.org/10.1002/ecs2.1931

Huntington HP, Goodstein E, Euskirchen E (2012) Towards a tipping point in responding to change: rising costs, fewer options for Arctic and global societies. Ambio 41:66-74. https://doi.org/10. 1007/s13280-011-0226-5

IPCC (2012) Glossary of terms. In: Field CB, Barros V, Stocker TF, Qin D, Dokken DJ, Ebi KL, Mastrandrea MD, Mach KJ, Plattner G-K, Allen SK, Tignor M, Midgley PM (eds) Managing the risks of extreme events and disasters to advance climate change adaptation, A special report of working groups I and II of the intergovernmental panel on climate change (IPCC). Cambridge University Press, Cambridge and New York, pp 555-564 https://archive.ipcc.ch/pdf/specialreports/srex/ SREX-Annex_Glossary.pdf. Accessed 18 Feb 2021

Jaakkola L, Heiskanen M, Lensu A, Kuitunen M (2013) Consequences of forest landscape changes on the availability of winter pastures for reindeer (Rangifer tarandus tarandus) from 1953 to 2003 in Kuusamo, Northeast Finland. Boreal Environ Res 18 https://jyx.jyu.fi/bitstream/handle/123456789/ 44533/1/lensukuitunenconsequencesofforestlandscapechanges. pdf. Accessed 18 Feb 2021

Jaakkola LM, Helle TP, Soppela J, Kuitunen MT, Yrjönen MJ (2006) Effects of forest characteristics on the abundance of alectorioid lichens in northern Finland. Can J For Res 36:2955-2965. https://doi. org/10.1139/x06-178

Johnsen KI (2016) Land-use conflicts between reindeer husbandry and mineral extraction in Finnmark, Norway: contested rationalities and the politics of belonging. Polar Geogr 39:58-79. https://doi.org/10. 1080/1088937X.2016.1156181

Kates RW, Travis WR, Wilbanks TJ (2012) Transformational adaptation when incremental adaptations to climate change are insufficient. Pros Natl Acad Sci 109:7156-7161. https://doi.org/10.1073/pnas. 1115521109 
Keskitalo ECH, Horstkotte T, Kivinen S, Forbes BC, Käyhkö J (2016) "Generality of mis-fit"? The real-life difficulty of matching scales in an interconnected world. Ambio 45:742-752. https://doi.org/10. 1007/s13280-015-0757-2

Kietäväinen A, Tuulentie S (2018) Trust matters-social capital in herding cooperation in Finland. Soc Nat Resour 31:1064-1079. https://doi. org/10.1080/08941920.2018.1463421

Kitti H, Gunslay N, Forbes BC (2006) Defining the quality of reindeer pastures: the perspectives of Sámi reindeer herders. In: Forbes BC, Bölter M, Müller-Wille L, Hukkinen J, Müller F, Gunslay N, Konstantinov Y (eds) Reindeer management in northernmost Europe: linking practical and scientific knowledge in socialecological systems. Ecol Stud 184. Springer, Berlin, pp 141165. https://doi.org/10.1007/3-540-31392-3

Kivinen S (2015) Many a little makes a mickle: Cumulative land cover changes and traditional land use in the Kyrö reindeer herding district, northern Finland. Appl Geogr 63:204-211. https://doi.org/10. 1016/j.apgeog.2015.06.013

Kivinen S, Kumpula T (2014) Detecting land cover disturbances in the Lappi reindeer herding district using multi-source remote sensing and GIS data. Int J Appl Earth Obs 27:13-19. https://doi.org/10. 1016/j.jag.2013.05.009

Kumpula J, Parikka P, Nieminen M (2000) Occurrence of certain microfungi on reindeer pastures in northern Finland during winter 1996-97. Rangifer 20:3-8. https://doi.org/10.7557/2.20.1.1477

Kumpula J, Colpaert A, Nieminen M (2002) Productivity factors of the Finnish semi-domesticated reindeer (Rangifer $\mathrm{t}$ tarandus) stock during the 1990s. Rangifer 22:3-12. https://doi.org/10.7557/2.22.1.387

Kumpula J, Colpaert A, Anttonen M (2007) Does forest harvesting and linear infrastructure change the usability value of pastureland for semi-domesticated reindeer (Rangifer tarandus tarandus)? In: Ann Zool Fennici Finnish zoological. Botanical Publishing Board, pp 161-178 https://www.jstor.org/stable/23736729. Accessed 18 Feb 2021

Kumpula J, Colpaert A (2009) Snow conditions and usability value of pastureland for semi-domesticated reindeer (Rangifer tarandus tarandus) in northern boreal forest area. Rangifer 27. https://doi. org/10.7557/2.27.1.171

Kumpula J, Kurkilahti M, Helle T, Colpaert A (2014) Both reindeer management and several other land use factors explain the reduction in ground lichens (Cladonia spp) in pastures grazed by semi-domesticated reindeer in Finland. Reg Environ Change 14:541-559. https://doi.org/10.1007/s10113-013-0508-5

Kumpula J, Siitari, S (2020) Kestävä biotalous porolaitumilla -hankkeen osaraportit, johtopäätökset ja toimenpide-ehdotukset. Luonnonvaraja biotalouden tutkimus 29/2020. Luonnonvarakeskus, Helsinki http://urn.fi/URN:ISBN:978-952-326-959-0. Accessed 18 Feb 2021

Kyllönen S, Colpaert A, Heikkinen H, Jokinen M, Kumpula J, et al. (2006) Conflict management as a means to the sustainable use of natural resources. Silva Fenn 40:687-728. http://urn.fi/URN:NBN: fi-fe2016101725311. Accessed 4 Jan 2021

Käyhkö J, Horstkotte T (2017) Reindeer husbandry under global change in the tundra region of Northern Fennoscandia. Publications from the Department of Geography and Geology, University of Turku. https://doi.org/10.13140/RG.2.2.22151.39841

Laakso AM (2008) The shadow field of reindeer management: a case study from Finland. Acta Boreal 25:138-159. https://doi.org/10. 1080/08003830802496703

Laaksonen S, Solismaa M, Kortet R, Kuusela J, Oksanen A (2009) Vectors and transmission dynamics for Setaria tundra (Filarioidea; Onchocercidae), a parasite of reindeer in Finland. Parasite Vector 2: 3. https://doi.org/10.1186/1756-3305-2-3

Laaksonen S, Pusenius J, Kumpula J, Venäläinen A, Kortet R et al (2010) Climate change promotes the emergence of serious disease outbreaks of filarioid nematodes. EcoHealth 7:7-13. https://doi.org/ 10.1007/s10393-010-0308-Z
Landauer M, Juhola S (2019) Loss and damage in the rapidly changing Arctic In: Mechler R, Bouwer L, Schinko T, Surminski S, Linnerooth-Bayer J (eds), Loss and damage from climate change. Climate risk management, policy and governance. Springer, Cham, pp 425-447. https://link.springer.com/chapter/10.1007/978-3-31972026-5_18. Accessed 4 Jan 2021

Landauer M, Komendantova N (2018) Participatory environmental governance of infrastructure projects affecting reindeer husbandry in the Arctic. J Environ Manag 223:385-395. https://doi.org/10.1016/j. jenvman.2018.06.049

Lee SE, Press MC, Lee JA, Ingold T, Kurttila T (2000) Regional effects of climate change on reindeer: a case study of the Muotkatunturi region in Finnish Lapland. Polar Res 19:99-105. https://doi.org/10. 3402/polar.v19i1.6535

Lépy É, Pasanen L (2017) Observed regional climate variability during the last 50 years in reindeer herding cooperatives of Finnish Fell Lapland. Climate 5:81. https://doi.org/10.3390/cli5040081

Lépy É, Heikkinen HI, Komu T, Sarkki S (2018) Participatory meaning making of environmental and cultural changes in reindeer herding in the northernmost border area of Sweden and Finland. Int J Business Glob 20:203. https://doi.org/10.1504/IJBG.2018.089868

Lonsdale K, Pringle P,Turner B (2015) Transformative adaptation: What it is, why it matters and what is needed. UK Climate Impacts Programme. University of Oxford, Oxford https://ukcip.ouce.ox. ac.uk/wp-content/PDFs/UKCIP-transformational-adaptation-final. pdf. Accessed 18 Feb 2021

Löf A (2013) Examining limits and barriers to climate change adaptation in an Indigenous reindeer herding community. Clim Dev 5:328 339. https://doi.org/10.1080/17565529.2013.831338

McGinnis MD, Ostrom E (2014) Social-ecological system framework: initial changes and continuing challenges. Ecol Soc 19 https://www. jstor.org/stable/26269580. Accessed 18 Feb 2021

McIntyre N, Bulovic N, Cane I, McKenna P (2016) A multi-disciplinary approach to understanding the impacts of mines on traditional uses of water in Northern Mongolia. Sci Total Environ 557:404-414. https://doi.org/10.1016/j.scitotenv.2016.03.092

Milkoreit M, Hodbod J, Baggio J, Benessaiah K, Calderón-Contreras R et al (2018) Defining tipping points for social-ecological systems scholarship - an interdisciplinary literature review. Env Res Letters 13. https://doi.org/10.1088/1748-9326/aaaa75

Ministry of Economic Affairs and Employment (2017) Government report on the National Energy and Climate Strategy of Finland for 2030. Publications of the Ministry of Economic Affairs and Employment 12/2017 http://julkaisut.valtioneuvosto.fi/bitstream/ handle/10024/79247/TEMjul_12_2017_verkkojulkaisu.pdf? sequence $=1$ \&isAllowed=y. Accessed 18 Feb 2021

Myers-Smith ICH, Elmendorf SC, Beck PS, Wilmking M, Hallinger M et al (2015) Climate sensitivity of shrub growth across the tundra biome. Nat Clim Chang 5:887-891. https://doi.org/10.1038/nclimate2697

Müller-Wille L, Hukkinen J, Müller F, Bölter M, Forbes BC (2006) Synthesis: environmental and sociopolitical conditions for modern reindeer management in Europe's north. In: Forbes BC, Bölter M, Müller-Wille L, Hukkinen J, Müller F, Gunslay N, Konstantinov Y (eds) Reindeer management in northernmost Europe: linking practical and scientific knowledge in social-ecological systems. Ecol Stud 184. Springer, Berlin, pp 365-379. https://doi.org/10.1007/3540-31392-3_18

Nelson DR, Adger WN, Brown K (2007) Adaptation to environmental change: contributions of a resilience framework. Annu Rev Environ Resour 32:395-419. https://doi.org/10.1146/annurev.energy.32. 051807.090348

Neuendorf KA (2016) The content analysis guidebook. Sage, Thousand Oaks, California

Nikander S, Laaksonen S, Saari S, Oksanen A (2007) The morphology of the filaroid nematode Setaria tundra, the cause of peritonitis in 
reindeer Rangifer tarandus. J Helminthol 81:49-55. https://doi.org/ 10.1017/S0022149X07214099

Normand S, Høye TT, Forbes BC, Bowden JJ, Davies AL et al (2017) Legacies of historical human activities in Arctic woody plant dynamics. Annu Rev 42:541-567. https://doi.org/10.1146/annurevenviron-110615-085454

Olofsson J, Oksanen L (2005) Effects of reindeer density on vascular plant diversity on North Scandinavian mountains. Rangifer 25:517. https://doi.org/10.7557/2.25.1.332

Olofsson J, Oksanen L, Callaghan T, Hulme PE, Oksanen T et al (2009) Herbivores inhibit climate-driven shrub expansion on the tundra. Glob Change Biol 15:2681-2693. https://doi.org/10.1111/j.13652486.2009.01935.x

Ostrom E (2009) A general framework for analyzing sustainability of social-ecological systems. Science 325:419-422. https://doi.org/ $10.1126 /$ science. 1172133

Pape R, Löffler J (2012) Climate change, land use conflicts, predation and ecological degradation as challenges for reindeer husbandry in Northern Europe: What do we really know after half a century of research? Ambio 41:421-434. https://doi.org/10.1007/s13280-0120257-6

Pekkarinen AJ, Kumpula J, Tahvonen O (2015) Reindeer management and winter pastures in the presence of supplementary feeding and government subsidies. Ecol Model 312:256-271. https://doi.org/10. 1016/j.ecolmodel.2015.05.030

Pelling M (2010) Adaptation to climate change: from resilience to transformation. Routledge, London

Pelto PJ, Linkola M, Sammallahti P (1968) The snowmobile revolution in Lapland. Suomalais-ugrilaisen seuran aikakauskirja $69 \mathrm{https}: / / \mathrm{www}$. sgr.fi/en/files/original/f10f0b9b86bb4ce119d41e71e68efc31.png. Accessed 18 Feb 2021

Rasmus S, Kivinen S, Irannezhad M (2018) Basal ice formation in snow cover in Northern Finland between 1948 and 2016. Environ Res Letters 13:114009. https://doi.org/10.1088/1748-9326/aae541

Rasmus S, Turunen M, Luomaranta A, Kivinen S, Jylhä K et al (2020) Climate change and reindeer management in Finland: co-analysis of practitioner knowledge and meteorological data for better adaptation. Sci Total Environ 710:136229. https://doi.org/10.1016/j. scitotenv.2019.136229

R Core Team (2020) R: a language and environment for statistical computing. R Foundation for Statistical Computing, Vienna, Austria. https://www.Rproject.org/. Accessed 18 Feb 2021

Reindeer Herders' Association (2021). Reindeer info. https://paliskunnat. fi/reindeer-herders-association/reindeer-info/. Accessed $18 \mathrm{Feb}$ 2021

Riseth JÅ, Tømmervik H, Forbes BC (2018) Sustainable and resilient reindeer herding. In: Tryland M, Kutz S(eds) Reindeer and caribou: health and disease. CRC Press/Taylor and Francis, Boca Raton, FL, pp 23-43

Ruosteenoja K, Jylhä K, Kämäräinen M (2016) Climate projections for Finland under the RCP forcing scenarios. Geophysica 51:17-50. http://www.geophysica.fi/pdf/geophysica_2016_51_1-2_017 ruosteenoja.pdf. Accessed 17 Mar 2021

Sámediggi (2021) The Sámi in Finland. https://www.samediggi.fi/samiinfo/?lang=en. Accessed 18 Feb 2021

Sarkki S, Komu T, Heikkinen HI, García NA, Lépy É et al (2016) Applying a synthetic approach to the resilience of Finnish reindeer herding as a changing livelihood. Ecol Soc 21:14. https://doi.org/10. 5751/ES-08819-210414

Sidortsov R, Ivanova A, Stammler F (2016) Localizing governance of systemic risks: A case study of the Power of Siberia pipeline in Russia. Energy Res Soc Sci:1654-1668. https://doi.org/10.1016/j. erss.2016.03.021

Speed JD, Austrheim G, Hester AJ, Mysterud A (2010) Experimental evidence for herbivore limitation of the treeline. Ecology 91:3414 3420. https://doi.org/10.1890/09-2300.1

Suopajärvi L, Ejdemo T, Klyuchnikova E, Korchak E, Nygaard V et al (2017) Social impacts of the "glocal" mining business: Case studies from Northern Europe. Miner Econ 30:31-39. https://doi.org/10. 1007/s13563-016-0092-5

Tahvonen O, Kumpula J, Pekkarinen AJ (2014) Optimal harvesting of an age-structured, two-sex herbivore-plant system. Ecol Model 272: 348-361. https://doi.org/10.1016/j.ecolmodel.2013.09.029

Tennekes M (2018) tmap: Thematic Maps in R. J Stat Softw 84:1-39. https://doi.org/10.18637/jss.v084.i06

Turunen M, Soppela P, Kinnunen H, Sutinen ML, Martz F (2009) Does climate change influence the availability and quality of reindeer forage plants? Polar Biol 32:813-832. https://doi.org/10.1007/ s00300-009-0609-2

Turunen M, Vuojala-Magga T (2014) Past and present winter feeding of reindeer in Finland: Herders' adaptive learning of feeding practices. Arctic:173-188. https://doi.org/10.1007/s00300-009-0609-2

Turunen MT, Rasmus S, Bavay M, Ruosteenoja K, Heiskanen J (2016) Coping with difficult weather and snow conditions: Reindeer herders' views on climate change impacts and coping strategies. Clim Risk Manage 11:15-36. https://doi.org/10.1016/j.crm.2016. 01.002

Turunen M, Rasmus S, Norberg H, Kumpula J, Kojola I, et al. (2017) Porot ja pedot - kuinka poronhoidon sopeutuminen petoihin on muuttunut 90 vuodessa? Suomen Riista 63:19-42

Turunen MT, Rasmus S, Järvenpää J, Kivinen S (2020) Relations between forestry and reindeer husbandry in northern Finland-perspectives of science and practice. For Ecol Manag 457:117677. https:// doi.org/10.1016/j.foreco.2019.117677

Vuojala-Magga T (2012) Adaptation of Sámi reindeer herding: EU regulation and climate change In: Tennberg M (ed) Governing the uncertain. Springer, Dordrecht, pp 101-122

Vuojala-Magga T, Turunen MT (2015) Sámi reindeer herders' perspective on herbivory of subarctic mountain birch forests by geometrid moths and reindeer: a case study from northernmost Finland. SpringerPlus 4:134. https://doi.org/10.1186/s40064-015-0921-y

Vuojala-Magga T, Turunen M, Ryyppo T, Tennberg M (2011) Resonance strategies of Sámi reindeer herders in northernmost Finland during climatically extreme years. Arctic:227-241 https:// www.jstor.org/stable/23025696. Accessed 18 Feb 2021

Wassmann P, Lenton TM (2012) Arctic tipping points in an earth system perspective. Ambio 41:1-9. https://doi.org/10.1007/s13280-0110230-9

Yin RK (2013) Case study research: Design and methods. Sage Publications, London

Publisher's note Springer Nature remains neutral with regard to jurisdictional claims in published maps and institutional affiliations. 